University of Nebraska - Lincoln

DigitalCommons@University of Nebraska - Lincoln

Biological Systems Engineering: Papers and

Publications

Biological Systems Engineering

$10-25-2017$

\title{
Spatial and temporal variation in precipitation in Togo
}

Koffi Djaman

Vivek Sharma

Daran Rudnick

Komlan Koudahe

Suat Irkmak

See next page for additional authors

Follow this and additional works at: https://digitalcommons.unl.edu/biosysengfacpub

Part of the Bioresource and Agricultural Engineering Commons, Environmental Engineering Commons, and the Other Civil and Environmental Engineering Commons

This Article is brought to you for free and open access by the Biological Systems Engineering at DigitalCommons@University of Nebraska - Lincoln. It has been accepted for inclusion in Biological Systems Engineering: Papers and Publications by an authorized administrator of DigitalCommons@University of Nebraska Lincoln. 


\section{Authors}

Koffi Djaman, Vivek Sharma, Daran Rudnick, Komlan Koudahe, Suat Irkmak, Kokou Adambounou Amouzou, and Jean Mianikpo Sogbedji 


\section{Spatial and temporal variation in precipitation in Togo}

\begin{abstract}
Precipitation is one of the important variables in hydrological cycle and has important application in both irrigated and rainfed agricultural crop production. Better understanding of spatio-temporal variability of precipitation across Togo is important and useful for water users and most agricultural activities. Thus, the objective this study was to analyze the spatial and temporal variation in monthly and annual precipitation across Togo for the period of 1961-2001. Monthly precipitation data was provided by the national direction of meteorology. The performed analysis revealed a decline in annual total precipitation across almost all agro-ecological zones in Togo with the Maritime Region revealed as the driest. Kouma-Konda received the greatest 40 year average annual precipitation in the country with $1714 \mathrm{~mm}$. June was the wettest month across Togo. The greatest coefficient of variation $(82 \%)$ in monthly precipitation was registered in January for the study period. Water management implications could be generated from this study, especially for rural and urban agricultural production zones. Mann Kendall's test was used to understand the temporal variation in precipitation over the period of 40 years. Decreasing trends in annual precipitation are likely to have significant impacts across Togo, where rainfed agriculture is widely practiced. On the other hand, persistent and progressive precipitation deficits are likely to cause recurrent drought and destroy plant cover, increase evapotranspiration, increase surface albedo and, affect other aspects of the water and energy balance.
\end{abstract}

Volume I Issue 4 - 2017

\author{
Koffi Djaman, ' Vivek Sharma, ${ }^{2}$ Daran R \\ Rudnick, ${ }^{3}$ Komlan Koudahe, ${ }^{4}$ Suat Irmak, ${ }^{3}$ \\ Kokou Adambounou Amouzou, ${ }^{5}$ Jean \\ Mianikpo Sogbedjij \\ 'Department of Plant and Environmental Sciences, New Mexico \\ State University, USA \\ ${ }^{2}$ Department of Plant Sciences, University of Wyoming, USA \\ ${ }^{3}$ Department of Biological Systems Engineering, University of \\ Nebraska-Lincoln, USA \\ ${ }^{4}$ Direction des Filieres Vegetales (DFV), Togo \\ ${ }^{5}$ Ecole Superieure d'Agronomie, Universite de Lome, Togo
}

Correspondence: Koffi Djaman, Department of Plant and Environmental Sciences, New Mexico State University, USA, Email kdjaman@nmsu.edu

Received:September 19,2017 | Published: October 25, 2017

Keywords: Rainfall, Variation, Spatio-temporal, Togo

\section{Introduction}

Reduction in seasonal precipitation is becoming recurrent, and many countries are concerned by the concept of climate change. Global surface temperature has increased by $0.74 \pm 0.18^{\circ} \mathrm{C}$ from 1906 to 2005 and it is projected that annual average runoff and water availability will decrease from 10 to $30 \%$ by the middle of $21^{\text {st }}$ century. ${ }^{1}$ Climate change has resulted in extreme drought condition in some parts of the world and flooding in other parts. ${ }^{2}$ Several studies have reported a drastic decrease in the principal climatic variable, precipitation, in Africa. ${ }^{3-7}$ Furthermore, it has been reported that most environmental changes in Africa are related to changes in precipitation. ${ }^{8,9}$ Observed that one of the most important contrasts in rainfall is the multi-decadal persistence of anomalies over northern Africa. ${ }^{10}$ Identified several changes in the general atmospheric circulation that have accompanied the shift to drier conditions in West African Sahel. ${ }^{11}$ Recent studies have revealed that the seasonal development of the tropical rain belt over Africa is driven by several factors of the general atmospheric circulation, which in turn, controls the location and characteristics of the inter-tropical convergence zone (ITCZ). ${ }^{9-14}$ This atmospheric circulation is believed to generate and maintain wave disturbances that modulate the precipitation field. Found the Tropical Easterly Jet (TEJ) as one of the most intense circulation features over Africa and they concluded that the TEJ may be a critical factor in the development of the rainy season and the overall climate in West Africa as opposed to the traditional belief of seasonal movements of the ITCZ. ${ }^{15}$ Suggested that the indirect effects of anthropogenic sulfate may have contributed to the drying of the Sahel in North Africa. ${ }^{16} \mathrm{~A}$ few studies in Togo revealed precipitation deficit since $1970 .{ }^{17-21}$ Validated the hypothesis of sensible decrease in water resources in West Africa since the beginning of the $1970 \mathrm{~s} .{ }^{22-25}$ Reported that in non-Sahelian West Africa, the rainfall regime began to change around 1966 in Senegal and Guinea Bissau, and then in Guinea, Mali, Burkina Faso, and the northern part of Benin. ${ }^{26}$ The Ivory Coast, Togo, the south of Benin, Cameroon and the Central African Republic have been affected by changes in precipitation patterns to various degrees. Variability in annual rainfall is characterized by the reduction in annual total precipitation, event frequency disorganization, occurrence of in-season drought when crops are at their critical growth stage (reproductive phase) which usually coincides with the highest evapotranspiration (ET) demand and the severity of the dry period. Reported that rainfed agriculture constitutes at least $97 \%$ of agriculture in all West African countries. In Togo where staple food production is not irrigated, particular attention has to be given to precipitation patterns in time and space for better cropping season determination to optimize soil water storage and in season precipitation for crop production. ${ }^{27}$ In addition, planting date for several crops need to is (re)adjusted according to the shifting of seasonal precipitation patterns over time. Furthermore, spatial analysis of long-term trends in precipitation can help identify areas that are experiencing an increase in the magnitude and frequency of high precipitation events which can generate abundant runoff and result in flood conditions, so that appropriate water and land management practices can be adopted to mitigate these effects. It can also help identifying areas that are experiencing severe drought for resilience and adaptation to climate change strategies development. Since the majority of agriculture in Togo is rainfed, precipitation patterns and distribution need to be investigated to enhance the short and longterm sustainability of crop production as well as the economy of the country. The objective of this study was to evaluate the spatial and temporal variation of monthly and annual average precipitation across Togo for deriving eventual impact on water resources availability and water management planning in rainfed and irrigated agriculture. 


\section{Materials and methods}

Study area : The study was conducted for Togo, West African country

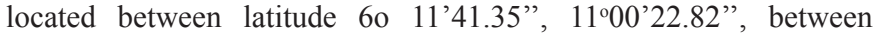
longitude $0^{\circ} 14^{\prime} 27.79^{\prime \prime}, 1^{\circ} 37^{\prime} 9.37^{\prime \prime}$. Togo is surrounded by Ghana at west, Benin Republic at East, Burkina-Faso at the north and by Atlantic Ocean at the south, with total coverage area of $56,000 \mathrm{~km}^{2}$ stretched over $600 \mathrm{~km}$ along the meridian 1 (North-south), and $50 \mathrm{~km}$ along the east-west. The Republic of Togo has a consolidated weather station network with about one hundred weather stations under the supervision of the National Direction of Meteorology (Figure 1). Thirty weather stations, representing the most agro-climatic zones of the country were considered in this research due to the unavailability or poor functionality of measurement equipment at some weather stations. Daily rainfall records were collected at all stations from 1961to2001. The normal distribution of the data was tested through the skewness coefficient that varied from -0.057 and 0.167 and falling within the reference range of $[-0.5,0.5] \cdot{ }^{28}$ Data are therefore normally distributed. Monthly means and standard deviations were calculated at all stations over the study period. Considering the extensive rainfed agriculture in Togo and the recent variation in climate, spatial and temporal information on precipitation would be very useful and contribute to overall improvement, planning and management of the water resources for agricultural production, natural resources management, ecological and hydrological water balance analysis.

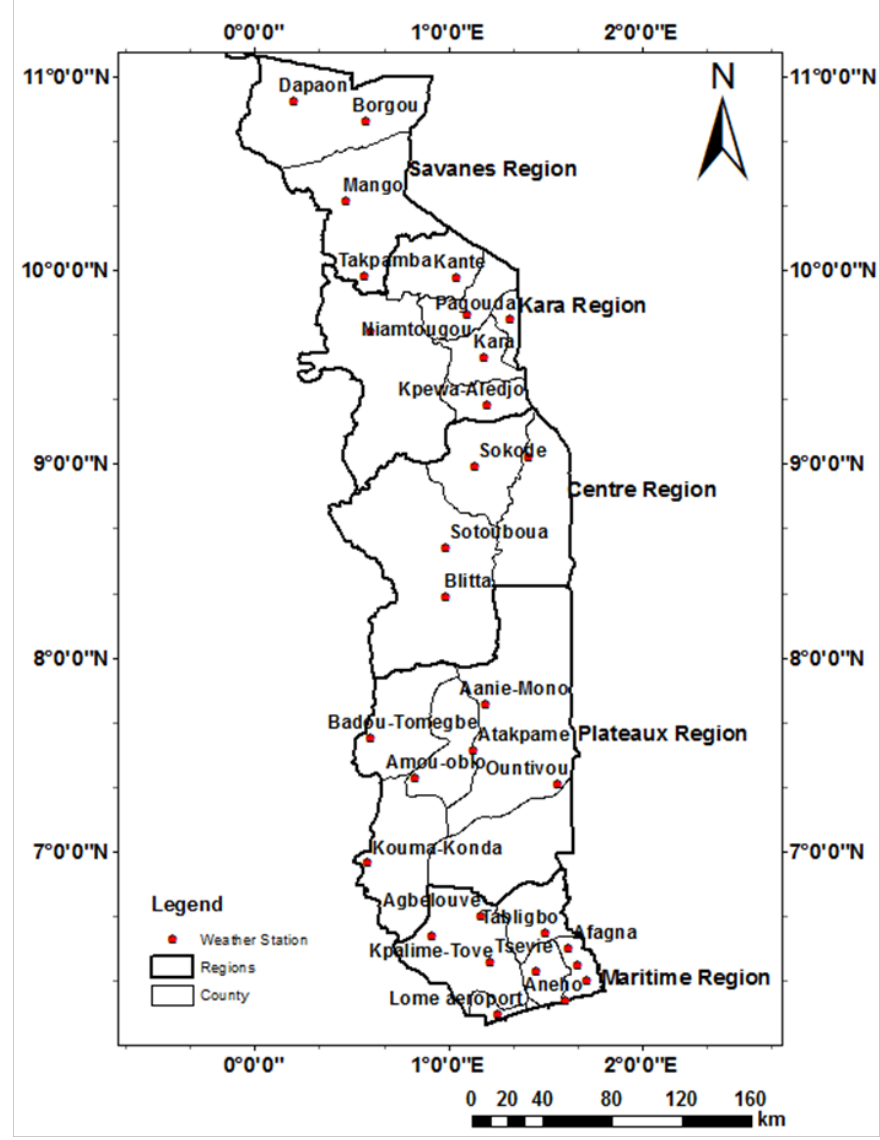

Figure I Study area and location of all weather stations used in the interpolation process.

Mapping spatial variation in the monthly rainfall across Togo: The predicted values of monthly and total annual rainfall based on 40 years of historical data were computed using the spline interpolation (Radial Basis Function) method which is an advanced, computationally intensive, geostatistical estimation method. ${ }^{29,30}$ Spline interpolation is a deterministic interpolation method that fits a mathematical function through input data to create a smooth surface. The functions allow users to decide between smooth curves or tight straight edges between measured points. It can generate the accurate surfaces from only few sampled points. Each station is omitted in turn from the estimation of the fitted surface, and the mean square error is calculated. The mean square error calculations are repeated for a range of values of a smoothing parameter, and the value that minimizes the mean square error is used to determine the optimum smoothing. This process is called minimizing the generalized cross-validation (GCV) or "leave one out" technique. In spline interpolation, surface is achieved through weights $\left(\gamma_{j}\right)$ and number of points $(\mathrm{N})$. We used regularized spline with maximum of five and minimum of three neighboring stations. The weight parameter defines the weight of the third derivatives of the surface in the curvature minimization. A higher weight creates a smoother gridded surface. We used the following spline function: ${ }^{31}$

$$
S(x, y)=T(x, y)+\sum_{j=1}^{\mathrm{N}} \lambda_{j} R\left(r_{j}\right)
$$

where, $\mathrm{T}$ is the constant trend, $\mathrm{r}_{\mathrm{j}}$ is the distance from point $(\mathrm{x}, \mathrm{y})$ to the jth point, $\mathrm{R}$ is a weighted function of the distance between the interpolated point and $\mathrm{j}^{\text {th }}$ data point $(\mathrm{j}=1,2,3 \ldots \mathrm{N}), \mathrm{N}$ is the number of known point and $\lambda_{\mathrm{i}}$ is the unknown weight for the measured values at the $\mathrm{j}^{\text {th }}$ location. For regularized spline interpolation, $\mathrm{T}$ and $\mathrm{r}$ is defined as:

$$
\begin{gathered}
T(x, y)=a_{1}+a_{2} x+a_{3} y \\
R(r)=\frac{1}{2 \pi}\left\{\frac{r^{2}}{4}\left[\ln \left(\frac{2}{2 \pi}\right)+c-1\right]+\tau^{2}\left[K_{o}\left(\frac{r}{\tau}\right)+c+\ln \left(\frac{r}{2 \pi}\right)\right]\right\}
\end{gathered}
$$

Where, $\tau$ is a weight parameter of the third derivatives of the surface in the curvature minimization expression, $\mathrm{r}$ is the distance between the point and the sample, $\mathrm{K}_{\mathrm{o}}$ is a modified Bessel function, and $\mathrm{c}$ is a constant (0.577). Coefficient $\mathrm{a}_{1}, \mathrm{a}_{2}, \mathrm{a}_{3}$ are found by the solution of a system of linear equations. The weight parameter was optimized, indicating the smoothness of the interpolant.

Temporal trends analysis in annual precipitation: Temporal trend in annual precipitation was analyzed using a nonparametric MannKendall test. ${ }^{32-34}$ It should be noted that the Mann-Kendall test statistic is non-dimensional, and it does not offer any quantification of the scale of the trend in the units of the time series under study, but is rather a measure of the correlation of a variable with time and, as such, simply offers information as to the direction and a measure of the significance of observed trends. The Mann-Kendall test statistic S is given as follows:

$$
S=\sum_{j=1}^{n-1} \sum_{i=j+1}^{n} \operatorname{sign}\left(x_{i}-x_{j}\right)
$$

Where $\mathrm{x}_{\mathrm{i}}$ is the data value at time $\mathrm{i}, \mathrm{n}$ is the length of the dataset, and sign () is the sign function which can be computed as:

$$
\operatorname{sign}\left(x_{i}-x_{j}\right)=\left\{\begin{array}{cc}
1 & \text { if }\left(x_{i}-x_{j}\right)>0 \\
0 & \text { if }\left(x_{i}-x_{j}\right)=0 \\
-1 & \text { if }\left(x_{i}-x_{j}\right)<0
\end{array}\right.
$$


For $\mathrm{n}>10$, the test statistic $\mathrm{Z}$ approximately follows a standard normal distribution:

$$
\mathrm{Z}= \begin{cases}\frac{\mathrm{S}-1}{\sqrt{\operatorname{Var}(\mathrm{S})}} & \text { if } S>0 \\ 0 \quad \text { if } S=0 \\ \frac{\mathrm{S}+1}{\sqrt{\operatorname{Var}(\mathrm{S})}} & \text { if } S<0\end{cases}
$$

Where $\operatorname{Var}(\mathrm{S})$ is the variance of statistic S. A positive value of $\mathrm{Z}$ indicates that there is an increasing trend and a negative value indicates a decreasing trend. The null hypothesis, $\mathrm{H}_{0}$, that there is no trend in the records is either accepted or rejected depending on whether the computed $\mathrm{Z}$ statistics is less than or more than the critical value of $\mathrm{Z}$ statistics obtained from the normal distribution table at the $5 \%$ significance level. ${ }^{29}$ If $|Z|>Z_{(1-\alpha / 2)}$, the null hypothesis of no autocorrelation and trend in dataset is rejected, in which $Z_{(1-\alpha / 2)}$ is corresponding to the normal distribution with $\alpha$ being the significance level.

If the data has a trend, the magnitude of trend can be denoted by trend slope $\beta[35-36]$ :

$$
\beta=\operatorname{Median}\left(\frac{x_{i}-x_{j}}{i-j}\right) \text { Where } \mathrm{i}>\mathrm{j}
$$

Where $x_{i}$ and $x_{j}$ are data values at time $t_{i}$ and $t_{j}(i>j)$, respectively.

Linear regression: Linear regression analysis was applied for analyzing trends in the time series. The main statistical parameter drawn from regression analysis is the slope, which indicates the mean temporal change in the variable under study. Positive values of the slope show increasing trends, while negative values of the slope indicate decreasing trends. The total change during the period under observation was obtained by multiplying the slope by the number of years. ${ }^{34-37}$

\section{Results and discussion}

Spatial variation in monthly precipitation across Togo: The spatial variation in mean monthly and annual precipitation across Togo is presented in Figure $2 \&$ Figure 3. While precipitation begins in the Maritime Region (south Togo) with the Kouma-Konda registering the highest amounts, there is progressing precipitation coverage from the south to northern Togo from January to May. June is the rainiest and wettest month across the country. The Central, Kara, and Savanes regions registered the highest monthly precipitation in July, August, and September averaging 197, 244, and $277 \mathrm{~mm}$, respectively, with the highest monthly precipitation registered at Kpewa-Aledjo in the Kara region (Figure 2). During these months, the southern part of Togo experienced a short dry season as shown in Figure 2. Thereafter, precipitation occurred mostly in the Maritime and Plateau regions from September to December, which comprised the second rainy season in the southern Togo. In November, Savanes regions received less than $10 \mathrm{~mm}$ of precipitation, while the Central and Kara regions received between 10 to $20 \mathrm{~mm}$. On annual basis, Kouma-Konda receiving $1,714 \mathrm{~mm}$ of precipitation, was revealed the most humid part of the country followed by Kpewa-Aledjo in the eastern part of the Kara Region which received 1,490mm of precipitation (Figure 3). The southern Maritime Region was revealed as the driest part of the country whenever it has two patterns of precipitation (Figure 4). The second growing season [September-November] total precipitation amount in the Maritime Region is decreasing and may disappear upon time with increase in July and August total precipitation as reported by. ${ }^{16}$ The results of this study could help crop growers, consultancy agencies, and researchers to adopt planning strategies to match water availability to the choice of crops and or varieties to be grown under rainfed and irrigated conditions. This study is a tremendous addition to the finding of ${ }^{21}$ that delimited the beginning and end of the crop growing season across Togo based on historical climatic data of the 1950-2000 period. Table 1 shows that the greatest variability in precipitation occurred in January $(\mathrm{CV}=82 \%)$, February $(\mathrm{CV}=65 \%)$, and December $(\mathrm{CV}=76 \%)$, while May and June registered the lowest $\mathrm{CV}$ of 10 and $15 \%$, respectively. Therefore, May and June had much more consistent precipitation across the country throughout the research period. In fact, June1st was decreed tree planting day due to the availability of soil water at planting to support plant growth. In addition, the results can help in designing irrigation systems, mostly pumping plants in different agro-ecosystems across the country. The accuracy of the precipitation interpolation across Togo varied among months with correlation coefficients ranging from 0.44 to 0.95 . August precipitation was associated with seasonal variability in precipitation and dependence on the location. While the August registered the lowest precipitation in the Maritime Region, the other four regions received almost year peak precipitation. Similar spatial precipitation variation among regions was registered in July and September (Figure 2). Overall, the interpolation was more accurate in the driest period of the year (January, February, and December) with RMSE values less than $6 \mathrm{~mm}$; whereas, September had the highest RMSE of $26 \mathrm{~mm}$.

Table I Descriptive statistics for mean monthly (nationwide) precipitation, and coefficient of determination $\left(\mathrm{R}^{2}\right)$, mean error $(\mathrm{ME})$, and root mean square error (RMSE) between observed and predicted monthly precipitation for Radial basis function computed from cross validation of weather stations for all $2 \mathrm{I}$ counties across Togo.

\begin{tabular}{lllllllll}
\hline & Average & Max & Min & SD & CV\% & $\mathbf{R}^{2}$ & Me & Rmse \\
\hline January & 6.15 & 20.18 & 0.14 & 5.07 & 82 & 0.7 & -0.12 & 3.26 \\
February & 18.09 & 41.46 & 2.39 & 11.69 & 65 & 0.81 & -0.03 & 5.86 \\
March & 59.87 & 112.31 & 17.08 & 26.42 & 44 & 0.86 & 0.56 & 10.86 \\
April & 102.02 & 148.37 & 55.28 & 24.21 & 24 & 0.74 & 0.57 & 14.73 \\
May & 135.34 & 159.28 & 103.25 & 13.93 & 10 & 0.44 & 0.77 & 16.19 \\
June & 177.72 & 227.63 & 142.6 & 26.16 & 15 & 0.69 & 2.21 & 17.5 \\
\hline
\end{tabular}




\begin{tabular}{|c|c|c|c|c|c|c|c|c|}
\hline & Average & Max & Min & SD & CV\% & $\mathbf{R}^{2}$ & Me & Rmse \\
\hline July & 178.27 & 244.71 & 86.2 & 51.94 & 29 & 0.89 & 0.14 & 18.34 \\
\hline August & 183.24 & 279.44 & 38.3 & 84.86 & 46 & 0.95 & -0.72 & 20.19 \\
\hline September & 189.36 & 264.46 & 73.93 & 62.46 & 33 & 0.86 & 0.91 & 25.81 \\
\hline October & 109.94 & 154.26 & 68.9 & 18.77 & 17 & 0.44 & $|.2|$ & $20.4 I$ \\
\hline November & 22.71 & 52.01 & 4.83 & 13.25 & 58 & 0.54 & 0.58 & 12.29 \\
\hline December & 10 & 30.31 & 1.62 & 7.65 & 76 & 0.88 & -0.29 & 2.96 \\
\hline
\end{tabular}
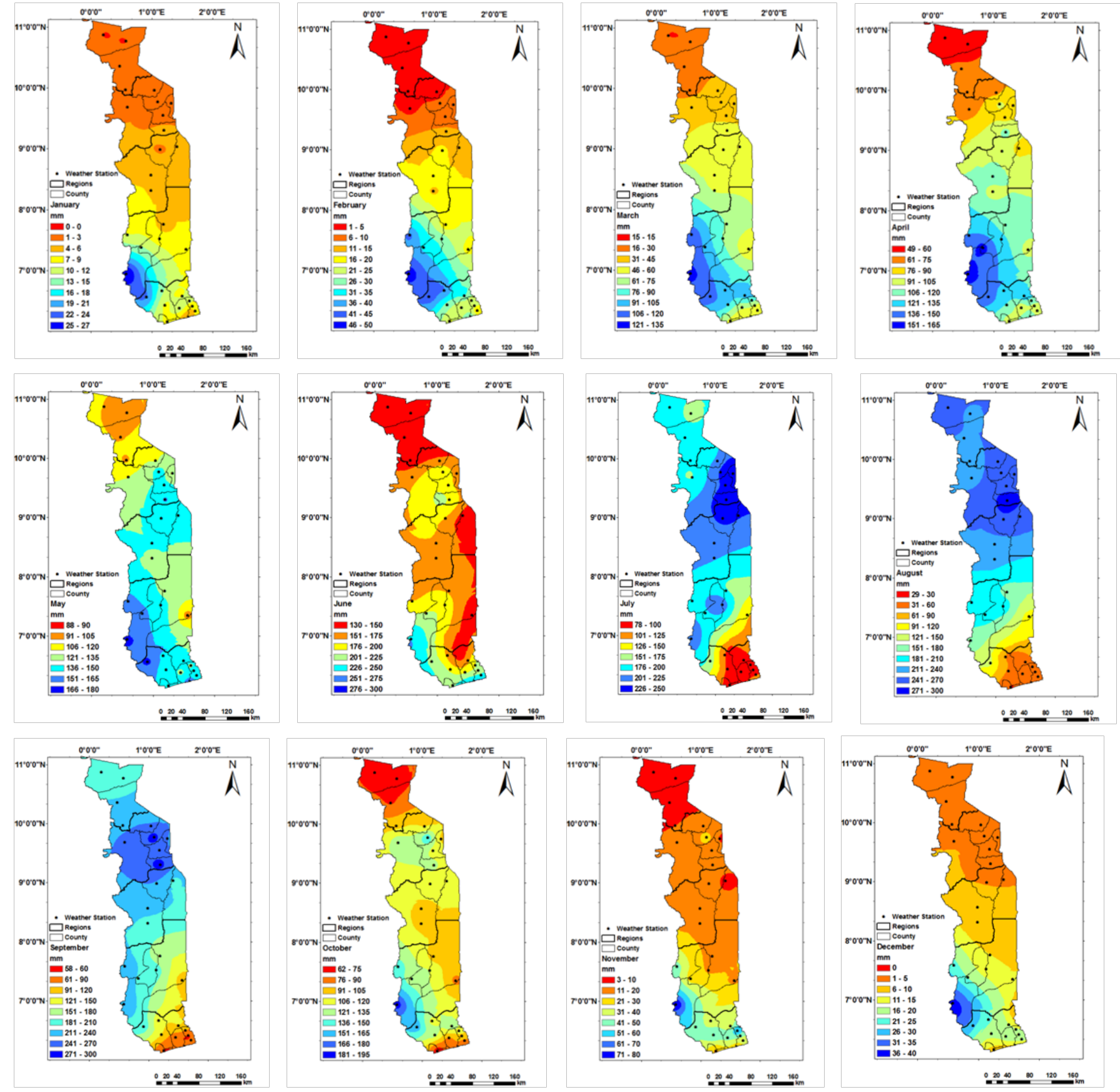

Figure 2 Spatial interpolation of long-term average monthly precipitation $(\mathrm{mm})$ across Togo. 


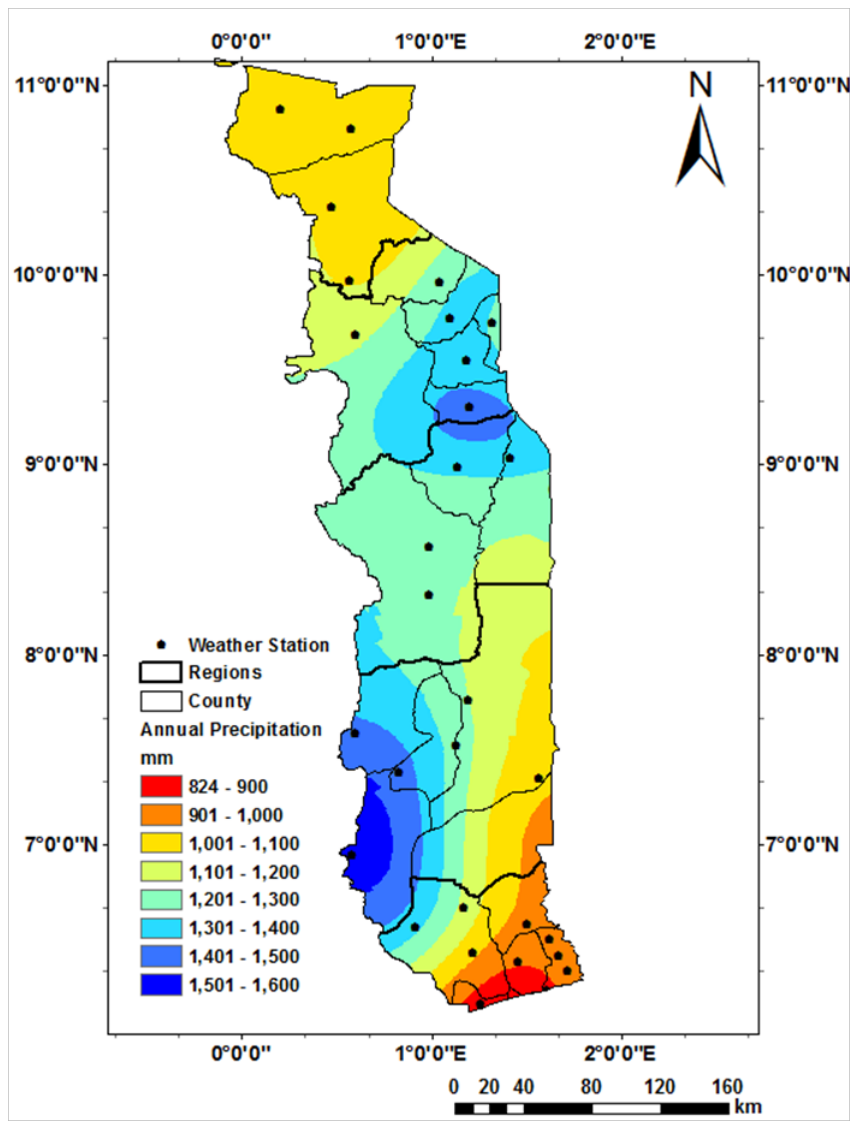

Figure 3 Spatial variation of annual precipitation across Togo.

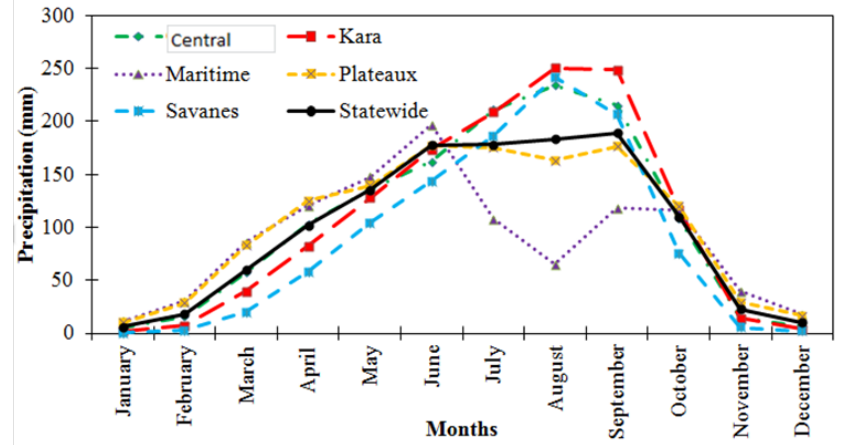

Figure 4 Comparison of monthly precipitation across different regions and country wide across Togo.

Temporal variation in precipitation across Togo: During the 1961-2001 period, annual precipitation decreased at $80 \%$ of the weather stations (Table 2). Annual total precipitation only showed an increasing trend at Anie-Mono, Sotouboua, Kara, Ontivou, Kante, and Takpamba. The magnitude of decrease in precipitation varied among regions with the highest decrease in the Maritime region. Precipitation reduction was more pronounced in the eastern part of the Maritime region where the Sen's slope estimates varied between -14.5 and $-2.6 \mathrm{~mm}$ (Table 2). This spatial heterogeneity in the declining rainfall pattern is consistent with earlier studied in West Africa. ${ }^{38-41}$ The decreasing trend in annual precipitation has a direct effect on stream flow, water availability for crop production, household, industries, and other water users. The highest annual precipitation $(2,339 \mathrm{~mm})$ was registered in 1989 at Kouma-Konda and the lowest annual precipitation $(335 \mathrm{~mm})$ was registered in 1967 at Ountivou. On the country average, there were years when below normal annual precipitation was registered, which caused intense drought and consequently, very low crop yield and famine to the most vulnerable families. Most staple food produced in Togo is rainfed, and consequently, crop production heavily declined during the drought years because water is the most critical factor that sustains crop productivity in rainfed agriculture. For example, we can cite the 1977 and 1983 droughts that caused tremendous famine across Africa. At national level, the 1961-2001 period mean precipitation varied from 824 to $1,714 \mathrm{~mm}$ (Table 2). The western part of the Plateaux region (Kouma-konda, Badou-Tomegbe, Kpalimé-Tove registered the highest annual average precipitation followed by the eastern part of Kloto County, the southern part of the Amou County, the southern part of Assoli County, and the northern part of the Tchaodjo County (Figure 3). The driest part of Togo is the extreme southern area, Vo, Lacs, Golf, Zio, and Yoto counties, which comprise the Maritime Region with average annual precipitation less than $1,000 \mathrm{~mm}$ where there are two rainy seasons as shown in Figure 5. Precipitation decline is more noticeable in South Togo with shift in the set of the first rainy season and the reduction of precipitation events and magnitude during the second rainy season. ${ }^{34}$ Some of the consequences are the decreasing trends in precipitation, increase in evapotranspiration, and a shift in the aridity index with environmental impacts, such as soil degradation and loss of biodiversity, loss of forest cover, increase in runoff, agricultural yields decline, reduction in agricultural revenue, and frequent famine caused partly by bad anthropogenic activities such as deforestation, overgrazing, urbanization, and farming close to rivers and water bodies. ${ }^{42}$ The Savanes Region received annual precipitation that ranged between 1,001 and $1,100 \mathrm{~mm}$. Regional average precipitation was 1,$050 ; 1,244 ; 1,269 ; 1,275 ;$ and $1,047 \mathrm{~mm}$ for the Maritime, Plateaux, Central, Kara, and Savanes regions, respectively (Figure 5). Declining rainfall has been reported throughout West Africa over the past 50 years and may be viewed in the long-term. ${ }^{43}$ Diagnostic studies provide information concerning the forcing of West Africa rainfall by global sea-surface temperature. ${ }^{44,45}$ Continental surface conditions also play a role in determining the persistence of the drought condition. ${ }^{46}$ The loss of vegetation, with the associated increase in soil albedo and increase in temperature, was proposed as a cause of Sahelian drought by. ${ }^{47}$ Large-scale rainfall deficits have the potential to destroy plant cover, increase evapotranspiration, increase surface albedo, and affect other aspects of the water and energy balance and set in motion a long period of below-normal rainfall. ${ }^{48,49}$ Similar to the results of this study, several studies have shown that West Africa registered notable variability in rainfall regime during the second half of the 20th century. ${ }^{6-53}$ Reported that long-term change in rainfall has occurred in the semi-arid and sub-humid zones of West Africa. ${ }^{54}$ Rainfall during the 30 year period of 1968 to 1997 was on average $15 \%$ to $40 \%$ lower than the 1931-1960 period. The concept of climate change is mostly demonstrated by drastic decrease in rainfall, which is the principal climatic variable identified for Africa in the literature. ${ }^{3-5}$ Found there are corresponding changes in the atmospheric circulation that is associated with the inter-decadal changes in summer precipitation over Asia and Africa ${ }^{55-60}$ The decrease in seasonal rainfall induced dramatic consequences on the agricultural production such as severe droughts of years 1970,1980,1984,and 2006 in many West African countries. Increasing drought frequency has the potential to affect land-based natural and managed ecosystems, coastal systems, and both 
freshwater quality and quantity. ${ }^{54-62}$ Agriculture is inherently sensitive to climate conditions, and is among the most vulnerable sectors to the risks and impacts of global climate change. ${ }^{63-64}$ Found that there is a relation between the rainfall disturbance and the water stress at critical period of maize growth and development in the Togo. ${ }^{65}$ Found that the decrease in seasonal rainfall amount represents a serious threat to maize growth during the second growing season. ${ }^{66}$ Adaptation to climate change and variability necessitates the adjustment of a system to moderate the impacts of climate change, to take advantage of new opportunities, and to cope with the consequences. ${ }^{67} \mathrm{~A}$ wide variety of adaptation options have been proposed as having the potential to reduce vulnerability of agricultural systems to risks related to climate change. Technology development and farm production practices such as drought resistant crops, adjusting planting dates and plant density, adoption of conservative and sustainable agriculture regarding soil and water management, altering and widening existing crop rotations, government policies, farm financial management and international trade, and agricultural insurance.$^{68-70}$ Human interference is also leading to climate change with changing land use from the impact of agricultural and irrigation practices. ${ }^{71}$ In Togo where rainfed agriculture is practiced by more than $90 \%$ of crop growers, greater attention is required when selecting and planting crops to optimize the available water to meet crop water demand as proposed by. ${ }^{21}$ The results of this study will aid crop consultants, food and fiber producers, and researchers to plan and manage rainfed and irrigated agriculture to improve water productivity across the territory of Togo for more sustainable production. Furthermore, the results of this study can be incorporated into the findings of ${ }^{21}$ to make adjustments to crop planting dates using past and current rainfall regimes as well as predicting the onset of the rainy season. Several approaches have been adopted for determining the date of onset of the rainy season. ${ }^{56}$ used the monthly rainfall minimum threshold of 60 and $30 \mathrm{~mm}$, respectively, to determine the onset of the rainy season. Defined the onset of growing season as the first ten day period of $20 \mathrm{~mm}$ of rain without any consideration of occurrence of any dry spell. ${ }^{72}$ Defined the onset of the rains as $20 \mathrm{~mm}$ in one or more date(s) within the next thirty days. ${ }^{73}$ Used a simple water balance approach consisting of daily potential ET. ${ }^{56}$ Defined the onset of the wet season as period of five days (pentad) with at least $25 \mathrm{~mm}$ of rainfall occurring. Crop ET models could also be used to determine the onset dates of the rainy season. ${ }^{74}$

Table 2 Summary of the temporal trends analysis in precipitation at 30 sites in Togo during the $|96|-200 \mid$ period

\begin{tabular}{|c|c|c|c|c|c|c|c|}
\hline \multirow[t]{2}{*}{ Locations } & \multirow[t]{2}{*}{ Mean (mm) } & \multirow[t]{2}{*}{ Test $\mathbf{Z}$} & \multirow[t]{2}{*}{ *Significance } & \multirow[t]{2}{*}{ Sen's slope estimate } & \multirow[t]{2}{*}{ Intercept (mm) } & \multicolumn{2}{|c|}{ Change in rain fall } \\
\hline & & & & & & $(\mathrm{mm})$ & $(\%)$ \\
\hline Lome-Aeroport & 823 & -2.24 & $*$ & -8.15 & 997 & -334 & -40.574 \\
\hline Aneho & 969 & -2.02 & $*$ & -7.43 & 1083 & -297 & -30.702 \\
\hline Akoumape & 857 & -1.81 & + & -5.9 & 961 & -236 & -27.55 \\
\hline Aklakou & 881 & -3.34 & $* * *$ & -10.78 & 1077 & -442 & -50.174 \\
\hline Attitogon & 907 & -1.57 & n.s & -4.63 & 1032 & -190 & -20.958 \\
\hline Afagna & 967 & -3.52 & $* * *$ & -12.63 & $|13|$ & -518 & -53.546 \\
\hline Tabligbo & 1028 & -0.73 & n.s & -2 & 1059 & -82 & -7.996 \\
\hline Tsevie & 1039 & -0.75 & n.s & -2.17 & 1088 & -89 & -8.548 \\
\hline Agbelouve & 1055 & -2.55 & $*$ & -7.38 & 1159 & -302 & -28.678 \\
\hline Kpalime-Tove & 1428 & -0.64 & n.s & -2.2 & 1434 & -90 & -6.312 \\
\hline Kouma-Konda & 1714 & -1.16 & n.s & -5.69 & 1713 & -233 & -13.602 \\
\hline Ountivou & 854 & 1.12 & n.s & 3.52 & 721 & 144 & 16.919 \\
\hline Amou-Oblo & $|44|$ & -0.86 & n.s & -2.69 & 1500 & -110 & -7.652 \\
\hline Badou-Tomegbe & 1469 & -0.58 & n.s & -2.4 & 1543 & -98 & -6.685 \\
\hline Atakpame & 1335 & -0.62 & n.s & -2.97 & $|36|$ & -122 & -9.106 \\
\hline Anie-Mono & 1129 & 0.55 & n.s & 2.18 & 1064 & 89 & 7.924 \\
\hline Blitta & 1201 & -2.39 & $*$ & -9.91 & 1379 & -406 & -33.846 \\
\hline Sotouboua & 1290 & 0.02 & n.s & 0.2 & 1300 & 8 & 0.65 \\
\hline Tchamba & 1235 & -0.78 & n.s & -3.61 & 1312 & -148 & -11.987 \\
\hline Sokode & 1349 & -2.3 & $*$ & -6.6 & 1493 & $-27 \mid$ & -20.061 \\
\hline Guerin-Kouka & 1192 & -0.75 & n.s & -1.12 & 1225 & -46 & -3.859 \\
\hline Kpewa-Aledjo & 1490 & -1.07 & n.s & -3.68 & 1538 & $-|5|$ & -10.116 \\
\hline
\end{tabular}


Table Continued....

\begin{tabular}{llllllll}
\hline Locations & Mean $(\mathbf{m m})$ & Test Z & *Significance & Sen's slope estimate & Intercept $(\mathbf{m m})$ & Change in rain fall \\
Kara-St & 1321 & 0.35 & n.s & 0.81 & 1244 & 33 & 2.502 \\
Pagouda & 1286 & -1.36 & n.s & -4.68 & 1353 & -192 & -14.935 \\
Nimtougou & 1408 & -1.74 & + & -4.15 & 1462 & -170 & -12.084 \\
Kante & 1221 & 0.21 & n.s & 0.28 & 1212 & 11 & 0.911 \\
Mango & 1069 & -1.15 & n.s & -2.01 & 1111 & -80 & -7.513 \\
Takpamba & 1074 & 1.15 & n.s & 3.22 & -1.591 & 132 & 12.303 \\
Borgou & 964 & -0.45 & n.s & -1.49 & 945 & -61 & -6.336 \\
Dapaon-St & 1025 & -0.24 & n.s & -0.64 & 1029 & -26 & -2.554
\end{tabular}

*Significance; n.s, Non significant+, significant at $5 \%$; , significant at I\%;***, significant at $0.1 \%$

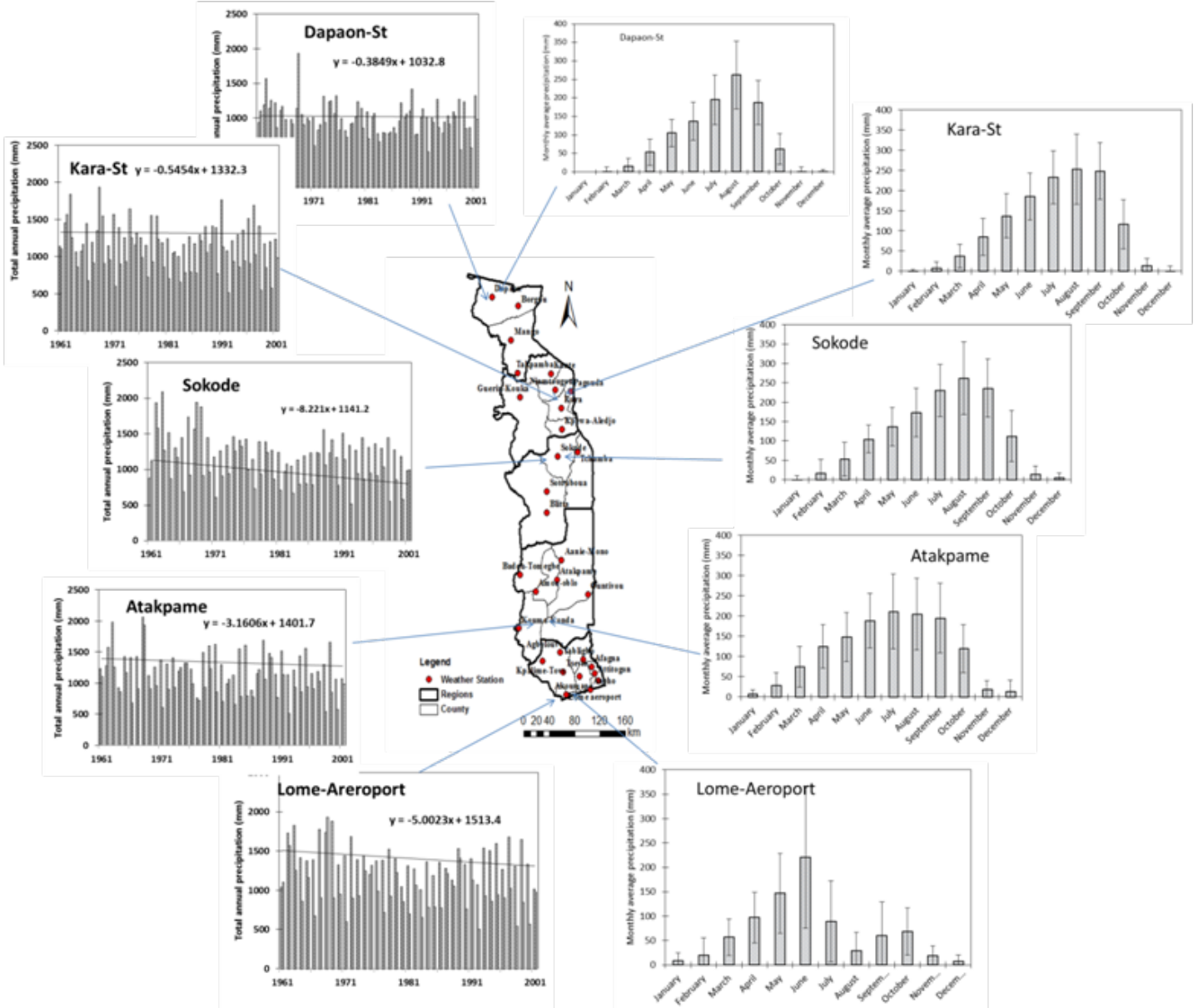

Figure 5 Spatial and temporal variability in monthly and annual regional rainfall in Togo for the 196I-200I period.

\section{Conclusion}

Better understanding of spatio-temporal variability in precipitation across Togo is important and useful for water users and most agricultural activities. The results of this study showed decline in annual total precipitation across almost all agro-ecological zones in Togo. The Maritime Region was revealed the driest and the Plateaux Region, the wettest. The Kouma-Konda site received the greatest 40 year average annual precipitation in the country with $1,714 \mathrm{~mm}$. June was the wettest month across Togo. The greatest coefficient of variation $(82 \%)$ in monthly precipitation was registered in January for the study period. The Mann-Kendall test revealed declining trends in annual precipitation at $80 \%$ of the weather stations. Therefore most part of the country is experiencing increase in the severity of aridity. The results of this study could be used by water management institutions, universities, and crop consultants for better panning when designing and managing rainfed and irrigated crop production systems in Togo.

\section{Acknowledgment}

None. 


\section{Conflict of interest}

None.

\section{References}

1. IPCC. Climate Change Synthesis Report. In: Core Writing Team, et al. editors. IPCC, The Intergovernmental Panel on Climate Change, Switzerland; 2007. p. 1-104.

2. Van de Giesen N, Liebe J, Jung G. Adaptation to climate change in the Volta Basin, West Africa. Current Science. 2010;98(8):1-5.

3. Hubert P, Carbonnel JP, Chaouche A. Segmentations des series hydrometeorologiques-application a des séries de précipitations et de débits de l'Afrique de l'Ouest. Journal of Hydrology. 1989;110(3-4):349-367.

4. Mahé G, Olivry JC . Variations des précipitations et des écoulements en Afrique de l'Ouest et Centrale de 1951 à 1989. Sécheresse 1995;6(1):109-117.

5. Bricquet JP, Bamba F, Mahe G, et al. Variabilité des ressources en eau de l'Afrique Atlantique. PHI-V. 1997;6:83-95.

6. Servat E, Paturel JE, Lubes-Niel H, et al. De différents aspects de la variabilité de la pluviométrie en Afrique de l'ouest et centrale non sahélienne. Revue des sciences de l'eau. 1999;12(2):363-387.

7. Balme-Debionne M. Analyse Du Regime Pluviometrique Sahelien Dans Une Perspective Hydrologique Et Agronomique. Etude De L'Impact De Sa Variabilite Sur La Culture Du Mil. INPG. 2004.

8. Zheng X, Eltahir EAB The response to deforestation and desertification in a model of West African monsoons. Geophysical Research Letters. 1997;24(2):155-158.

9. Nicholson SE. Climatic and environmental change in Africa during the last two centuries. Climate Research. 2001;17:123-144.

10. Nicholson SE. Land surface processes and Sahel climate. Reviews Geophysics. 2000;38:1-23

11. Nicholson SE, Grist JP. A simple conceptual model for understanding rainfall variability in the West African Sahel on interannual and interdecadal time scales. International Journal of Climatology. $2001 ; 21: 1-25$

12. Zheng X, Basher Reid E, Thompson-Craig S, et al. Trend Detection in Regional-Mean Temperature Series: Maximum, Minimum, Mean, Diurnal Range, and SST. Journal of Climate. 1997;10:317-326.

13. Grist JP, Nicholson SE, Barcilon AI. Easterly Waves over Africa. Part II Observed and Modeled Contrasts between Wet and Dry Years. Monthly Weather Review. 2002;130:1-14.

14. Nicholson SE, Grist JP. On the seasonal evolution of atmospheric circulation over West Africa and Equatorial Africa. Journal of Climate. 2003;16:1013-1030

15. Nicholson SE, Barcilon AI, Challa M, et al. Wave Activity on the Tropical Easterly Jet. JAS. 2007;64:2756-2763.

16. Rotstayn LD, Lohmann U. Tropical Rainfall Trends and the Indirect Aerosol Effect. JCLI. 2002;15:2103-2116.

17. Badameli KSM. La variabilité climatique et la production agricole au Togo. Université de Bordeaux III, France; 1996. p. 1-343.

18. Badameli KSM. Analyse et prise de compte des risques climatiques en agriculture: cas de la region maritime du Togo. Travaux et recherches geographiques. Revue Geographique de' 'Universite de Lome; 1998. p. 239-250.

19. Klassou KS. Evolution climato-hydrologique récente et conséquences sur l'environnement : l'exemple du bassin versant du fleuve Mono
(Togo-Bénin). Thèse de Doctorat, France; 1996.

20. Adewi E. Strategies agricoles de gestion de la crise climatique au Togo. DEA Universite de Lomé, Togo; 2002. p. 1-90.

21. Adewi E, Badameli KM, Dubreuil V. Evolution des saisons des pluies potentiellement utiles au Togo de 1950 à 2000. Climatologie. 2010;7:1-19.

22. Sutcliffe JV, Knott DG. Historical Variations in African Water Resources. IASH Publ. 1987;168:1-14.

23. Nicholson SE, Tucker CJ, Ba MB. Desertification, drought, and surface vegetation: an example from the West African Sahel. Bulletin of the American Meteorological Society. 1998;79:815-829.

24. Mahé G, Olivry JC. Changements climatiques et variations des écoulements en Afrique occidentale et centrale, du mensuel à l'interannuel. AISH Publ. 1991;20:163-172.

25. Olaniran OJ.Rainfall anomaly patterns in dry and wet years over Nigeria. International Journal of Climatology. 1991;11(2):177-204.

26. Gautier H, Varlet-Granncher C, Hazard L. Tillering responses to the light environment and to the defoliation in populations of perennial ryegrass (Loliumperenne L.) selected for contrasting leaf length. Annals of Botany. 1999;83(4):423-429.

27. Gleick PH. Water in Crisis: A Guide to the World's Fresh Water Resources. Oxford University Press, New York; 1993. p. 1-15.

28. Figueiredo F, Gomes I . The Skew-Normal Distribution in SPC. Statistical Journal. 2013;11(1):1-22.

29. Sharma V, Irmak S. Mapping spatially-interpolated rainfall, reference evapotranspiration, actual crop evapotranspiration, and net irrigation requirements: Part I. Rainfall and reference evapotranspiration. Transactions of the ASABE. 2012;55(3):907-921.

30. Franke R. Smooth interpolation of scattered data by local thin plate splines. Computers and Mathematics with Applications. 1982;8(4):273-281.

31. Sharma V, Irmak S, Djaman K, et al. Large scale spatial and temporal variability in evapotranspiration and crop water use efficiency of irrigated and rainfed maize and soybean. Journal of Irrigation and Drainage Engineering. 2015;142(3):1.

32. Mann HB. Non-parametric test against trend. Econometrica $1945 ; 13(3): 245-259$

33. Kendall MG. Rank Correlation Methods, 4th Ed. London, UK: Charles Griffin; 1975.

34. Djaman K, Ganyo K. Trend analysis in reference evapotranspiration and aridity index in the context of climate change in Togo. Journal of Water and Climate Change. 2015;6(4):848-864.

35. Sen PK. Estimates of the regression coefficient based on Kendall's TAU. J Am Statistical Assoc. 1968;63(324):1379-1389.

36. Theil HA. Rank-invariant method of linear and polynomial regression analysis. Nederlandse Akademie Wetenchappen Series A 1950;53:386-392.

37. Tabari H, Marofi S. Changes of pan evaporation in the west of Iran.Water Resources Management. 2011;25(1):97-111.

38. Servat E, Paturel JE, Lubès H, et al. Climatic variability in humid Africa along the Gulf of Guinea. Part one: Detailed analysis of the phenomenon in Côte d'Ivoire. Journal of Hydrology. 1997;191(1997):1-15.

39. Gyau-Boakye P, Tumbulto JW. The Volta lake and declining rainfall and stream flows in the Volta river basin. Environment. Development and Sustainability. 2000;2(1):1-11.

40. Jenkins R, McCulloch A, Friedli L. Developing a National Mental Health Policy (Maudsley Monographs) Psychology Press, UK; 2002.p.1-213. 
41. Owusu K, Waylen P, Youliang Q. Changing rainfall inputs in the Volta basin: implications for water sharing in Ghana. Geo Journal. 2008;71(4):201-210.

42. Logah FY, Obuobie E, Ofori D, et al. Analysis of Rainfall Variability in Ghana. International Journal of Latest Research In Engineering and Computing (IJLREC). 2013;1(1):1-8.

43. Weldeab S, Lea DW, Schneide RR, et al. 155,000 years of West African monsoon and ocean thermal evolution. Science. 2007;316(5829):1303-1307.

44. Ward MN. Diagnosis and short-lead time prediction of summer rainfall in tropical North Africa at interannual and multidecadal timescales. Journal of Climate. 1998;11:3167-3191.

45. Giannini A, Saravanan R, Chang P. Oceanic forcing of Sahel rainfall on interannual to interdecadal time scales. Science. 2003;302(5647):1027-1030.

46. Zheng X, Eltahir EAB. The Role of Vegetation in the Dynamics of West African Monsoons. Journal of Climate. 1998;11:2078-2096.

47. Charney JG. Dynamics of deserts and drought in the Sahel. Quaterly Journal of the Royal Meteorological Society. 1975;101(428):193-202.

48. Lare AR, Nicholson SE. Contrasting conditions of surface water balance in wet and dry years as a possible land surface-atmosphere feedback mechanism in the West African Sahel. Journal of Climate. 1994; 7:653-668.

49. Owusu K, Waylen P. Trends in spatio-temporal variability in annual rainfall in Ghana (1951-2000). Royal Meteorological Society Weather. 2009;64(5):115-120.

50. Nicholson SE, Palao IM. A re-evaluation of rainfall variability in the Sahel, Part I. Characteristics of rainfall fluctuations. International Journal of Climatology. 1993;13(4):371-389.

51. Le Barbé L, Lebel T, Tapsoba D. Rainfall variability in West Africa during the years 1950-90. Journal of Climate. 2002;15:1-16.

52. Lebel T, Ali A. Recent trends in the Central and Western Sahel rainfall regime (1990-2007). Journal of Hydrology. 2009;375(1-2):52-64.

53. Zhang X, He J, Zhang J, et al. Enhanced Poleward Moisture Transport and Amplified Northern High-Latitude Wetting Trend. Nature Climate Change. 2012;3:47-51.

54. Nicholson SE, Some B, Kone B. An analysis of recent rainfall conditions in West Africa, including the rainy seasons of the $1997 \mathrm{El}$ Nino and the 1998 La Nina Years. Journal of Climate. 2000;13:1-13.

55. Trilsbach A, Hulme M. Recent rainfall changes in central Sudan and their physical and human implications. Transactions of the Institute of British Geographers. 1984;15:280-298.

56. Hulme M. Rainfall in Sudan: An asset or liability. Geoforum 1987;18(3):321-331.
57. Hulme M. The changing rainfall resources of Sudan. Transactions of the Institute of British Geographers. 1990;15(1):21-34.

58. Walsh RPD, Hulme M, Campbell MD. Recent rainfall changes and their impact on hydrology and water supply in the semi-arid zone of the Sudan. The Geographical Journal. 1988;154(2):181-198.

59. Hulme M, Tosdevin N. The Tropical Easterly Jet and Sudan rainfall: A review. Theoretical and Applied Climatology. 1989;39(4):179-187.

60. Quan XW, Diaz HF, Fu CB. Interdecadal change in the Asian-Africa summer monsoon and its associated changes in global atmospheric circulation. Global and Planetary Change. 2003;37:1-24.

61. Janowiak J. An investigation of interannual variability in Africa. Journal of Climate. 1998;1:1-16.

62. Alvi SH. Climate changes, desertification and the Republic of Sudan Geo Journal. 1994;33(4):393-399.

63. Parry ML, Carter TR. An Assessment of Effects of Climate Change on Agriculture. Climatic Change. 1989;15:95-116.

64. Reilly JM. Climate Change and Global Agriculture: Recent Findings and Issues. American Journal of Agricultural Economics (Proceedings). 1995;77:727-733.

65. Adewi E, Badameli KSM, Dubreuil V. Influence de la péjoration pluviométrique sur les Productions agricoles au Togo. Geographia Technica Numéro special, Togo; 2009. p. 1-495.

66. Sogbedji JM. Maize nitrogen utilization and nitrate leaching modeling in Togo and New York. USA: Cornell University; 1999. p. 1-194.

67. IPCC. Climate Change 2001-IPCC Third Assessment Report. UK: Cambridge University Press; 2001. p. 1-3.

68. Smith JB, Lenhart SS. Climate change adaptation policy options. Climate Research. 1996;6(2):193-201.

69. Smith B, Skinner MW. Adaptation options in agriculture to climate change: a typology. Mitigation and Adaptation Strategies for global Change. 2002;7(1):85-114.

70. Howden SM, Soussana JF, Tubiello FN, et al. Adapting agriculture to climate change. Proceedings of the National Academy of Sciences of the USA; 2007;104(50):19691-19696.

71. Kalnay E, Cai M. Impact of urbanization and land-use on climate change. Nature. 2003;423:528-531.

72. Davey EG, Mattie F, Solomon SI. An evaluation of climate and water resources for the development of agriculture in the Sudan Savannah zone of West Africa. World Meteorological Organization (WMO) Special Environment Report No. 9, Switzerland; 1976. p. 1-310.

73. Stern RD, Dennett MD, Garbutt DJ. The start of the rains in West Africa J Climatol. 1981;1(1):59-68.

74. Edoga NR. Determination of length of growing season in Samaru using different potential evapotranspiration models. AUJT. 2007;11(1):28-35. 